\title{
Erratum to: Design and pilot validation of A-gear: a novel wearable dynamic arm support
}

Peter N. Kooren ${ }^{1 *}$, Alje G. Dunning ${ }^{2,3}$, Mariska M. H. P. Janssen ${ }^{4}$, Joan Lobo-Prat ${ }^{5}$, Bart F. J. M. Koopman ${ }^{5}$, Micha I. Paalman', Imelda J. M. de Groot ${ }^{4}$ and Just L. Herder ${ }^{2,6}$

Unfortunately, the original version of this article [1] contained an error. Equation 6 was included incorrectly: in the original equation variable $s_{\text {links } 3}$ was missing.

The correct Equation 6 can be found below:

$$
s_{3}=\frac{m_{F A} \cdot s_{F A}+m_{\text {link } 3} \cdot s_{\text {link } 3}}{m_{3}}
$$

\section{Author details}

${ }^{1}$ Department of Physics and Medical Technology, VU Medical Center, Amsterdam, The Netherlands. ${ }^{2}$ Department of Precision \& Microsystems Engineering, Delft University of Technology, Delft, The Netherlands. ${ }^{3}$ Department of Biomechanical Engineering, Delft University of Technology, Delft, The Netherlands. ${ }^{4}$ Department of Rehabilitation, Donders Center for Neuroscience, Radboud University Medical Center, Nijmegen, The Netherlands. ${ }^{5}$ Department of Biomechanical Engineering, University of Twente, Enschede, The Netherlands. ${ }^{6}$ Department of Mechanical Automation, University of Twente, Enschede, The Netherlands.

Received: 26 November 2015 Accepted: 26 November 2015 Published online: 04 December 2015

\section{References}

1. Kooren PN, Dunning AG, Janssen MM, Lobo-Prat J, Koopman BF, Paalman $\mathrm{Ml}$, et al. Design and pilot validation of A-gear: a novel wearable dynamic arm support. J Neuroeng Rehabil. 2015;12:83.

\footnotetext{
* Correspondence: p.kooren@vumc.nl

${ }^{1}$ Department of Physics and Medical Technology, VU Medical Center, Amsterdam, The Netherlands

Full list of author information is available at the end of the article

Submit your next manuscript to BioMed Central and we will help you at every step:

- We accept pre-submission inquiries

- Our selector tool helps you to find the most relevant journal

- We provide round the clock customer support

- Convenient online submission

- Thorough peer review

- Inclusion in PubMed and all major indexing services

- Maximum visibility for your research

Submit your manuscript at www.biomedcentral.com/submit 